\title{
Weibull distribution and dynamics of germination of Rangpur lime seeds at different temperatures ${ }^{1}$
}

\author{
Marizangela Rizzatti Ávila ${ }^{2}$, Juliana Barbosa ${ }^{2}$, Nelson da Silva Fonseca Júnior ${ }^{2}$, \\ Getúlio Takashi Nagashima², Carolina Maria Gaspar de Oliveira ${ }^{2 *}$ (iD)
}

\begin{abstract}
Rangpur lime is the most commonly used rootstock in Brazil, and its propagation occurs through seeds. Currently, no methodology is described in the prescriptions of the Rules for Seed Testing to perform the germination test of Rangpur lime. Thus, this research aimed to study the dynamics of germination in Rangpur lime seeds according to the Weibull distribution under the effect of different temperatures and lots. The experiment was conducted in a completely randomized design, with treatments arranged in a $3 \times 5$ factorial scheme (temperatures of 25,30 and $35{ }^{\circ} \mathrm{C}$ for the germination test and five seed lots, respectively) and four replications. The percentage of germination, the number of days required obtaining $50 \%$ of germination, and the parameters of the Weibull equation were determined. The optimum temperature for germination of Rangpur lime seeds was $30{ }^{\circ} \mathrm{C}$, with the first and last counts at 21 and 30 days after test installation, respectively. The germination process can be described by the three-parameter Weibull cumulative distribution function.
\end{abstract}

Index terms: Citrus limonia Osbeck, germination curves, rootstock, viability.

\section{Distribuição de Weibull e dinâmica do processo germinativo de sementes de limão 'cravo' em diferentes temperaturas}

\begin{abstract}
RESUMO - O limão-cravo é o porta-enxerto mais utilizado no Brasil e sua propagação ocorre por meio de sementes. Atualmente nas prescrições das Regras de Análise de Sementes não há metodologia descrita para realização do teste de germinação de limão-cravo. Dessa forma, o objetivo foi estudar a dinâmica da germinação em sementes de limão-cravo de acordo com a distribuição de Weibull, sob o efeito de diferentes temperaturas e lotes. $\mathrm{O}$ experimento foi conduzido em delineamento inteiramente casualizado, com os tratamentos dispostos em esquema fatorial $3 \times 5$ (temperaturas de 25 , 30 e $35{ }^{\circ} \mathrm{C}$ na condução do teste de germinação e cinco lotes de sementes, respectivamente), com quatro repetições. Foram determinadas a porcentagem de germinação, o número de dias necessários para se obter $50 \%$ de germinação e os parâmetros da equação de Weibull. A temperatura mais favorável para germinação de sementes de limão-cravo foi a de $30^{\circ} \mathrm{C}$, com a primeira contagem aos 21 dias e a última contagem aos 30 dias após a instalação do teste. O processo germinativo pode ser descrito pela função de distribuição acumulativa de Weibull com três parâmetros.
\end{abstract}

Termos para indexação: Citrus limonia Osbeck, curvas de germinação, porta-enxerto, viabilidade.

\section{Introduction}

The propagation in the various species of citrus rootstocks is carried out using seeds, which results in a better development of the taproot system of the seedling and, consequently, of the plant, thus requiring high physiological quality seeds.

Indicators obtained in the germination test are essential to the production planning of seedlings producer since the commercialization of citrus seeds requires the evaluation of seed viability through germination or tetrazolium tests (Brasil, 2013).

Thus, the objective of the germination test is to determine the maximum germination potential of a seed lot (Brasil, 2009; Marcos-Filho, 2015). In general, there is a defined methodology for most species to carry out the germination test, which is

\footnotetext{
${ }^{1}$ Submitted on 10/01/2018. Accepted for publication on 05/30/2019.

${ }^{2}$ IAPAR. Instituto Agronômico do Paraná, 86047-902 - Londrina, PR, Brasil.

*Corresponding author <carolina@iapar.br>
} 
conducted under controlled conditions of some or all external factors, allowing a regular, fast, and complete germination.

The use of a standardized procedure for the installation, conduction, and evaluation of the germination test allows for achieving comparable results between official and accredited laboratories. However, the Brazilian rules for seed testing have no reference regarding the methodology for carrying out the citrus germination test (Brasil, 2009).

For the Rangpur lime rootstock, the most used in Brazil, Carvalho et al. (2002) observed higher percentages of germination on paper when seeds were maintained at $25^{\circ} \mathrm{C}$, with counts carry out on the sixteenth and thirtieth days after test installation. Similarly, Dantas et al. (2010) used the same methodology in paper rolls and performed a count only on the thirtieth day after test installation.

Seed germination of some citrus rootstocks occurs slowly, requiring sixty days or more to germinate (Monselise and Halevy, 1962; Mobayen, 1980; Rodrigues et al., 2010). However, because citrus seeds are recalcitrant, with a rapid loss of viability, the germination test must be carried out in a short period so that the seeds can be commercialized quickly, avoiding storage (Martins and Silva, 2006; Salisbury and Ross, 2012).

A growth curve, represented by mathematical equations such as the asymptotic exponential, logistic, Gompertz, and Weibull, can be constructed during the germination process. Although these equations are expressed numerically, they allow interpreting their parameters biologically (McNair et al., 2012; Ritz et al., 2013; Guedes et al., 2014).

The three-parameter Weibull model is efficient in describing the cumulative germination in Rangpur lime seeds, providing a complete and accurate adjustment, close to the real germination data, and may be suitable for statistical analysis (Carneiro and Guedes, 1992; 1993).

The model has also been used in studies of the germination potential of different species, such as Daucus carota L. (Carneiro and Guedes, 1992), Stevia rebaudiana (Takahashi et al., 1996; Carneiro, 1996), and Agave sp. (RamírezTobías et al., 2012). However, all these studies have adopted germination as radicle protrusion, which is seen as a botanical parameter, being different from seed technology, in which the end of the germination process culminates in the formation of a normal seedling, as discussed in the present study.

In this context, this research aimed to evaluate the germination test procedure of Rangpur lime seeds from different lots and temperatures and study the dynamics of germination according to the Weibull distribution.

\section{Material and Methods}

The experiment was conducted at the Laboratory of Seed Analysis in the Instituto Agronômico do Paraná (IAPAR), Londrina, PR, Brazil. Five lots of Rangpur lime seeds of the cultivar IPR 162, genetic category, obtained from fruits harvested from parent plants in 2015 and 2016 at the Luiz Natal Bonin Experimental Station in Cambará, PR, were used in this study. These lots were available for commercialization at IAPAR at that moment.

Seeds of each lot were mechanically extracted from pulped fruits, and mucilage removal was performed by successive washing with water. Subsequently, these seeds were dried under a suspended platform with a screen until reaching the water content of approximately $20 \%$, determined in an oven regulated at $105 \pm 3^{\circ} \mathrm{C}$ for 24 hours (Brasil, 2009). The seeds were cleaned, classified, and treated with fungicide composed of Captan 480 g.L $\mathrm{L}^{-1}$ after reaching the desired humidity. Then, they were packed in polyethylene bags, which were hermetically sealed and stored in a cold room regulated at $5{ }^{\circ} \mathrm{C}$ and $40 \%$ relative humidity until laboratory tests were conducted.

The experiment was carried out in a completely randomized design in a $5 \times 3$ factorial scheme, with factors consisting of five lots and three temperatures for the germination test $(25,30$ and $35^{\circ} \mathrm{C}$ ) and four replications of 50 seeds.

The germination test was performed on a paper roll using three sheets of paper for germination $\left(\right.$ Germitest $\left.^{\circledR}\right)$ moistened with distilled water in a ratio 2.5 times their mass when dry (Brasil, 2009), using four replications of 50 seeds.

Seeds remained with the seed coat (integument) in the sowing. The micropyle was positioned in the inferior direction of the fold of the paper necessary for preparing the roll. The rolls were taken to Mangelsdorf germinators set at 25, 30 and $35{ }^{\circ} \mathrm{C}$, where seeds remained until the test was finished. The germinators were located in a germination room under a controlled environment with a constant temperature of $20{ }^{\circ} \mathrm{C}$ and unchanged lighting with a compact white fluorescent lamp of $220 \mathrm{~V}, 85 \mathrm{~W}$ and $6400 \mathrm{~K}$ (lux).

Evaluations started at 24 hours after test assembly, being performed daily at the same time by determining the percentage of normal seedlings and, at the end of the test when no more seeds without germination were observed, the percentage of abnormal seedlings and non-germinated seeds.

Dead seeds were considered those with no sign of the beginning of germination, softened samples, and usually attacked by microorganisms (Figure 1A). Normal seedlings showed a straight growth root, i.e., without tortuosity or coiling and thickening, and length of at least $2 \mathrm{~cm}$, straight

Journal of Seed Science, v.41, n.3, p.328-335, 2019 
and well-developed hypocotyl, apparent or well-formed leaflets without damage (Figure 1B). On the other hand, abnormal seedlings were those that did not fit into the description of normal seedlings, but emitted root (Figure 1C). Polyembryonic seeds (Figure 1D) were considered normal seedlings, being considered as only one seedling, according to Brasil (2009).

Seed performance was represented by regression curves of the accumulated germination as a function of time through the three-parameter Weibull function (Weibull, 1951; Carneiro and Guedes, 1992; Takahashi et al., 1996; Guedes et al., 2014), using the computational application Table Curve 2D (Jandel Scientific, 1994) by the model:

$$
G_{(\%)}=a\left(1-\exp \left(-\left((\mathrm{x} / b)^{\wedge c}\right)\right)\right), a>0,
$$

where $G$ is the cumulative percentage of germination, $a$ is the asymptote of the maximum percentage of accumulated germination, i.e., the maximum value of estimated germination ( $\%$ of germination), $b$ is the time (days) estimated to obtain $63.21 \%$ of the maximum germination estimated by the regression (parameter $a$ ), $c$ is the germination progression rate as a function of the time $b$ (percentage of germination at day $b$ ), $\mathrm{x}$ is the germination time (days), and exp is the base of the natural or neperian logarithm.

The three parameters of the equation $(a, b$, and, $c)$ were obtained from the regression equation obtained by the Weibull distribution model for each of the 15 treatments formed by the combination of five lots and three temperatures.

The time needed to reach $50 \%$ of germination (T50W) was based on the absolute value of the total seeds used in the test and calculated by the reverse of the Weibull equation (Weibull, 1951), adapted to the data of seed germination by Carneiro and Guedes $(1992 ; 1993)$, in which the values of $Y$ $(\%$ of germination $=50 \%)$ and parameters of the respective equation for each lot, temperature, and replication were already known, according to the expression:

$$
X=\left\{\{[L N((Y / a)-1)(-1)](-1)\}^{(1 / c)}\right\}(b),
$$

where $X$ is the estimated number of days required to obtain $50 \%$ of germination (T50W, days), $\mathrm{LN}$ is the neperian logarithm (base e), $a$ is the asymptote of the maximum percentage of accumulated germination, i.e., the maximum value of estimated germination ( $\%$ of germination), $b$ is the time (in days) estimated to obtain $63.21 \%$ of the maximum germination estimated by the regression $(a), c$ is the germination progression rate as a function of time $b$, expressed as percentage of germination per day, and $Y$ is the percentage of accumulated germination previously stipulated in 50\%.

The data of germination test, time required to reach $50 \%$ of germination, and parameters $a, b$, and $c$, obtained by the Weibull distribution model, were submitted to analysis of variance by the F-test with $\mathrm{p}<0.05$, considering the treatments arranged in a 5 (lots) $\times 3$ (temperatures of 25, 30 and $35^{\circ} \mathrm{C}$ ) factorial scheme with four replications of 50 seeds in a completely randomized design, totaling a population of 200 seeds for each treatment. The necessary slicing was carried out in the presence of significant interaction since the marginal means of both lots and temperatures do not represent what actually occurred at each situation generated

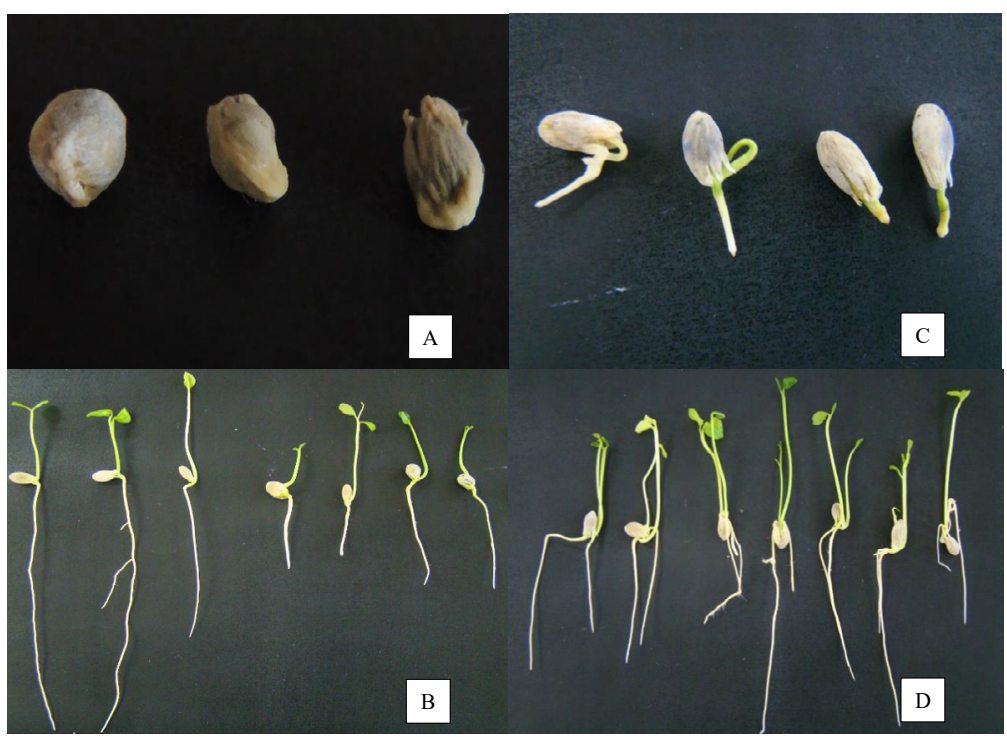

Figure 1. Seedlings and seeds of Rangpur lime observed in the germination test evaluation: dead seeds [A], normal seedlings [B], abnormal seedlings [C], and polyembryonic seedlings [D]. IAPAR, Londrina, PR (Photos: Willian Cason, 2014). 
by the interaction of lots $x$ temperatures. The study of each combination of lots within the same temperature (lot/ temperature) and temperatures within each lot (temperature/ lot) were performed using the Tukey's test at $5 \%$ probability.

\section{Results and Discussion}

The analysis of variance detected a significant effect at $5 \%$ probability for lots, temperatures, and their interaction in all studied variables, except for T50W (Table 1).

The response of the percentage of germination $(\mathrm{G} \%)$ of Rangpur lime seeds in the comparison of the three temperatures for each of the five lots was similar, with the highest values when the test was conducted at 25 and $30{ }^{\circ} \mathrm{C}$. However, the percentage of germination was lower for all lots at $35^{\circ} \mathrm{C}$.

These results show that the germination test of Rangpur lime seeds is negatively influenced by the temperature of $35^{\circ} \mathrm{C}$, identified by the occurrence of seedling abnormalities mainly caused by thickening and shortening of the root system. The same was observed by Pinheiro et al. (2014), who analyzed the effect of temperature on onion germination.

When seeds are exposed to temperatures above the optimum, plasma membrane changes and denaturation of cell enzymes that compose the seeds can occur (Araújo-Neto et al., 2002; Wahid et al., 2007; Salisbury and Ross, 2012). For this reason, a higher seedling abnormality (Figures 1 and 2) and, consequently, a lower percentage of germination were observed.

A significant difference was observed between lots within each temperature. Lots 2,4 , and 5 showed a percentage of germination similar and higher than $80 \%$ when the test was conducted at 25 and $30{ }^{\circ} \mathrm{C}$. However, a significant difference was observed in relation to lots 1 and 3, which did not differ from each other and presented germination below $80 \%$ (Table 1).

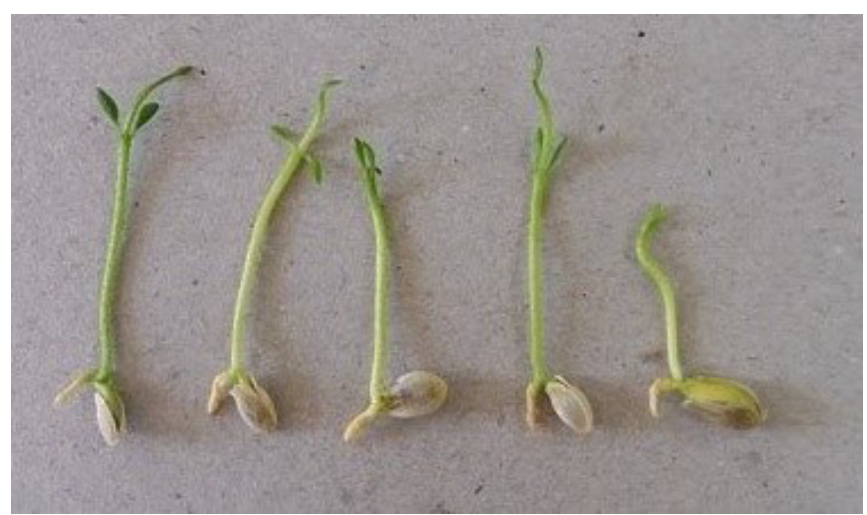

Figure 2. Abnormal seedlings of Rangpur lime: root thickening and shortening. IAPAR, Londrina, PR (Photo: Juliana Barbosa, 2016).
Table 1. Germination, parameters $a, b$, and $c$ of the Weibull regression, and T50W for five lots of Rangpur lime seeds obtained in the germination test conducted at different temperatures.

\begin{tabular}{ccccc}
\hline G $(\%)$ & \multicolumn{3}{c}{ Temperature $\left({ }^{\circ} \mathrm{C}\right)^{2}$} & Mean \\
\cline { 1 - 4 } Lot $^{1}$ & 25 & 30 & 35 & \\
\cline { 1 - 4 } 1 & $75 \mathrm{Ab}$ & $74 \mathrm{Ab}$ & $34 \mathrm{Bc}$ & 61 \\
2 & $90 \mathrm{Aa}$ & $90 \mathrm{Aa}$ & $45 \mathrm{Bbc}$ & 75 \\
3 & $72 \mathrm{Ab}$ & $75 \mathrm{Ab}$ & $46 \mathrm{Bb}$ & 64 \\
4 & $86 \mathrm{Aa}$ & $89 \mathrm{Aa}$ & $61 \mathrm{Ba}$ & 79 \\
5 & $89 \mathrm{Aa}$ & $91 \mathrm{Aa}$ & $66 \mathrm{Ba}$ & 82 \\
\hline Mean & 82 & 84 & 50 &
\end{tabular}

LSD of lots: 10.53; LSD of temperatures: 8.96 ; Coefficient of variation (\%): 7.16

\begin{tabular}{ccccc}
$\begin{array}{c}a(\% \text { of } \\
\text { germination })\end{array}$ & \multicolumn{3}{c}{ Temperature $\left({ }^{\circ} \mathrm{C}\right)^{2}$} & \multirow{2}{*}{ Mean } \\
\cline { 1 - 4 } Lot $^{1}$ & 25 & 30 & 35 & \\
\hline 1 & $71 \mathrm{Ab}$ & $68 \mathrm{Ab}$ & $35 \mathrm{Bb}$ & 58 \\
2 & $88 \mathrm{Aa}$ & $87 \mathrm{Aa}$ & $36 \mathrm{Bb}$ & 70 \\
3 & $71 \mathrm{Ab}$ & $70 \mathrm{Ab}$ & $40 \mathrm{Bb}$ & 60 \\
4 & $83 \mathrm{Aa}$ & $85 \mathrm{Aa}$ & $62 \mathrm{Ba}$ & 77 \\
5 & $85 \mathrm{Aa}$ & $87 \mathrm{Aa}$ & $68 \mathrm{Ba}$ & 80 \\
\hline Mean & 80 & 79 & 48 &
\end{tabular}

LSD of lots: 10.97; LSD of temperatures: 11.58; Coefficient of variation (\%): 7.83

\begin{tabular}{ccccc}
\hline$b^{3}$ & \multicolumn{3}{c}{ Temperature $\left({ }^{\circ} \mathrm{C}\right)^{2}$} & \multirow{2}{*}{ Mean } \\
\cline { 1 - 4 } Lot $^{1}$ & 25 & 30 & 35 & \\
\cline { 1 - 4 } 1 & $25.82 \mathrm{Aa}$ & $21.77 \mathrm{Ba}$ & $22.26 \mathrm{Bb}$ & 23.29 \\
2 & $22.63 \mathrm{Ab}$ & $19.54 \mathrm{Bb}$ & $15.40 \mathrm{Cc}$ & 19.19 \\
3 & $25.79 \mathrm{Aa}$ & $21.77 \mathrm{Ba}$ & $20.54 \mathrm{Bb}$ & 22.70 \\
4 & $26.88 \mathrm{Aa}$ & $21.98 \mathrm{Ba}$ & $26.33 \mathrm{Aa}$ & 25.06 \\
5 & $27.04 \mathrm{Aa}$ & $22.26 \mathrm{Ba}$ & $25.68 \mathrm{Aa}$ & 24.99 \\
\hline Mean & 25.63 & 21.46 & 22.04 & \\
\hline
\end{tabular}

LSD of lots: 2.11; LSD of temperatures: 1.80; Coefficient of variation (\%): 4.53

\begin{tabular}{|c|c|c|c|c|}
\hline \multirow{2}{*}{$\begin{array}{c}c^{4} \\
\operatorname{Lot}^{1}\end{array}$} & \multicolumn{3}{|c|}{ Temperature $\left({ }^{\circ} \mathrm{C}\right)^{2}$} & \multirow{2}{*}{ Mean } \\
\hline & 25 & 30 & 35 & \\
\hline 1 & $7.88 \mathrm{Aa}$ & $6.52 \mathrm{Ba}$ & $3.62 \mathrm{Cb}$ & 6.01 \\
\hline 2 & $6.83 \mathrm{Aa}$ & $5.72 \mathrm{ABa}$ & $5.10 \mathrm{Ba}$ & 5.88 \\
\hline 3 & $6.81 \mathrm{Aa}$ & $6.66 \mathrm{Aa}$ & 4.86 $\mathrm{Bab}$ & 6.11 \\
\hline 4 & $8.13 \mathrm{Aa}$ & $6.75 \mathrm{Ba}$ & $4.59 \mathrm{Cab}$ & 6.49 \\
\hline 5 & $7.89 \mathrm{Aa}$ & $6.40 \mathrm{Ba}$ & 4.14 Cab & 6.14 \\
\hline Mean & 7.51 & 6.41 & 4.46 & \\
\hline
\end{tabular}

LSD of lots: 1.43; LSD of temperatures: 1.22; Coefficient of variation $(\%): 11.58$ 
Table 1. Continuation.

\begin{tabular}{|c|c|c|c|c|}
\hline \multirow{2}{*}{$\frac{\mathrm{T}^{2} 0 \mathrm{~W}^{5}}{\text { Lot }^{1}}$} & \multicolumn{3}{|c|}{ Temperature $\left({ }^{\circ} \mathrm{C}\right)^{2}$} & \multirow{2}{*}{ Mean } \\
\hline & 25 & 30 & 35 & \\
\hline 1 & 26.7 & 22.9 & - & $24.8 \mathrm{a}$ \\
\hline 2 & 22.1 & 19.1 & - & $20.6 \mathrm{~b}$ \\
\hline 3 & 26.8 & 22.6 & - & $24.7 \mathrm{a}$ \\
\hline 4 & 26.6 & 21.6 & - & $24.1 \mathrm{a}$ \\
\hline 5 & 26.6 & 21.7 & - & $24.2 \mathrm{a}$ \\
\hline Mean & $25.7 \mathrm{~A}$ & $21.6 \mathrm{~B}$ & - & \\
\hline
\end{tabular}

LSD of lots: 1.83; LSD of temperatures: 1.28; Coefficient of variation (\%): 3.70

${ }^{1}$ Means followed by the same uppercase letter in the row do not differ from each other by the Tukey's test at $5 \%$ probability.

${ }^{2}$ Means followed by the same lowercase letter in the column do not differ from each other by the Tukey's test at $5 \%$ probability.

${ }^{3}$ Estimated time (days) to obtain $63.21 \%$ of the maximum germination estimated by the regression (parameter $a$ ).

${ }^{4}$ Germination progression rate as a function of time $b$ (percentage of germination at day $b$ ).

${ }^{5}$ Time required to reach $50 \%$ of germination.

At a temperature of $35^{\circ} \mathrm{C}$, lots 4 and 5 had the highest percentage of germination (above 60\%), while significant differences were observed between lots 1,2 and 3, with a percentage of germination below 50\%, which would compromise their commercialization (Table 1).

Among the parameters of the Weibull function, the maximum values of estimated germination (parameter a) were lower than and/or equal to that of the estimated maximum germination (Table 1) when each lot was compared at different temperatures (Table 1). These results reinforced that the germination test of Rangpur lime seeds is negatively influenced by the temperature of $35^{\circ} \mathrm{C}$.

Seeds from lots 1 and 3 had similar results at temperatures of 30 and $35^{\circ} \mathrm{C}$ for the parameter $b$ of the Weibull regression, which indicates the time to obtain $63.21 \%$ of germination. However, this time was lower when germination occurred at $25^{\circ} \mathrm{C}$. On the other hand, a lower time was observed at $35^{\circ} \mathrm{C}$ in lot 2. Lots 4 and 5 had the highest results at 25 and $35^{\circ} \mathrm{C}$ when compared to $30^{\circ} \mathrm{C}$.

In general, the highest means for the parameter $b$ of the Weibull equation were observed in seeds submitted to a temperature of $25^{\circ} \mathrm{C}$ for all lots, indicating the need for more time to reach $63.21 \%$ of the estimated maximum germination, i.e., seed germination at this temperature is slower.

Lot 2 reached $63.21 \%$ of the estimated maximum germination in lower time at temperatures of 25 and $30{ }^{\circ} \mathrm{C}$ when compared to the other lots. However, lots 4 and 5 needed a longer time to reach the estimated germination at $35^{\circ} \mathrm{C}$.
A significant interaction was observed between lots and temperatures for the parameter $c$ of the Weibull regression, which is equivalent to the germination progression rate accumulated as a function of time (Table 1).

Among the temperatures, the highest percentages of accumulated germination per day were identified at $25{ }^{\circ} \mathrm{C}$, regardless of the lots, followed by 30 and $35^{\circ} \mathrm{C}$. A difference was observed between lots at $35^{\circ} \mathrm{C}$, with higher values for lot 2 , lower for lot 1 , and intermediate values for the other seed lots.

The result of T50W was significant for both lots and temperatures, with no interaction between factors. The parameter was not analyzed with the data of temperature of $35^{\circ} \mathrm{C}$ because only lots 4 and 5 presented mean values above $50 \%$ under this condition.

The germination process was faster under a temperature of $30{ }^{\circ} \mathrm{C}$, requiring a mean of 21.6 days to reach $50 \%$ of germinated seeds. Lot 2 was the first to reach $50 \%$ of germination at 20.6 days after test installation, while the others needed 24 days. In this case, it took approximately 22 days for Rangpur lime seeds to obtain $50 \%$ of germination at $30{ }^{\circ} \mathrm{C}$, which is minimum for commercialization.

In this sense, the temperatures of 25 and $30{ }^{\circ} \mathrm{C}$ can be defined as optimal for germination and, consequently, for conducting the germination test of Rangpur lime seeds since ideal temperatures for maximum seed germination are obtained by the percentage of normal seedlings at the shortest mean time and best uniformity (Suñé and Franke, 2006; Gaspar-Oliveira et al., 2008).

The regression parameters for the percentage of accumulated germination as a function of time by the Weibull model (Table 2) showed that the germination process dynamics was represented by the regression equations of the three-parameter model. The calculation of the Weibull equation allowed determining the percentage of germination on all days and at all temperatures (Figure 3).

The curves for the temperature of $30^{\circ} \mathrm{C}$ (Figure 4) showed that the performance of each lot is similar due to a tendency of the germination curve at the three tested temperatures (Figure 3).

The three-parameter Weibull model was efficient in describing the cumulative germination as it provided a complete and accurate adjustment, close to the real data of germination performance of Rangpur lime seeds, and may be adequate to perform statistical analysis. The same was observed by Carneiro and Guedes (1992) in a study with carrots and Royo-Esnal et al. (2010) in a study with weeds of the genus Galium.

Thus, the results found in this study showed that the germination of Rangpur lime seeds occurs under wide temperature ranges. However, temperature variation can affect the speed, 
percentage, and uniformity of the germination process, which should be determined for its efficiency (Marcos-Filho, 2015).

It occurs because the temperature interferes directly with water absorption and biochemical reactions, as well as in the germination power and seedling development (Lopes and Franke, 2011). Usberti and Felippe (1980) observed that the germination of Rangpur lime seeds did not occur at temperatures below $25^{\circ} \mathrm{C}$.

Table 2. Regression equations of the three-parameter Weibull model for five lots of Rangpur lime seeds obtained in the germination test conducted at different temperatures.

\begin{tabular}{|c|c|c|c|c|c|}
\hline $\begin{array}{c}\text { Temperature } \\
25^{\circ} \mathrm{C}\end{array}$ & \multicolumn{3}{|c|}{ Weibull regression parameters } & Weibull equation & $\mathrm{R}^{2}$ \\
\hline $\operatorname{Lot}^{1}$ & $a$ & $b$ & $c$ & $G_{(\%)}=a\left(1-\exp \left(-\left((\mathrm{x} / b)^{\wedge c}\right)\right)\right)$ & - \\
\hline 1 & $71.00 \pm 2.07$ & $25.82 \pm 0.44$ & $7.88 \pm 0.84$ & $\mathrm{G}_{(\%)}=71\left(1-\exp \left(-\left((\mathrm{x} / 25.82)^{\wedge 7.88}\right)\right)\right)$ & 0.99 \\
\hline 2 & $88.00 \pm 2.69$ & $22.63 \pm 0.50$ & $6.83 \pm 0.41$ & $\mathrm{G}_{(\%)}=88\left(1-\exp \left(-\left((\mathrm{x} / 22.63)^{\wedge 6.83}\right)\right)\right)$ & 0.99 \\
\hline 3 & $71.00 \pm 0.40$ & $25.79 \pm 0.33$ & $6.81 \pm 1.42$ & $\mathrm{G}_{(\%)}=71\left(1-\exp \left(-\left((\mathrm{x} / 25.79)^{\wedge 6.81}\right)\right)\right)$ & 0.99 \\
\hline 4 & $83.00 \pm 1.66$ & $26.88 \pm 0.32$ & $8.13 \pm 0.71$ & $\mathrm{G}_{(\%)}=83\left(1-\exp \left(-\left((\mathrm{x} / 26.88)^{\wedge 8.13}\right)\right)\right)$ & 0.99 \\
\hline 5 & $85.00 \pm 2.20$ & $27.04 \pm 0.31$ & $7.89 \pm 0.97$ & $\mathrm{G}_{(\%)}=85\left(1-\exp \left(-\left((\mathrm{x} / 27.04)^{\wedge 7.89}\right)\right)\right)$ & 0.99 \\
\hline $\begin{array}{c}\text { Temperature } \\
30^{\circ} \mathrm{C}\end{array}$ & \multicolumn{3}{|c|}{ Weibull regression parameters } & Weibull equation & $\mathrm{R}^{2}$ \\
\hline Lot $^{1}$ & $a$ & $b$ & $\mathrm{c}$ & $G_{(\%)}=a\left(1-\exp \left(-\left((\mathrm{x} / b)^{\wedge c}\right)\right)\right)$ & - \\
\hline 1 & $68.00 \pm 2.93$ & $21.77 \pm 0.51$ & $6.52 \pm 1.08$ & $\mathrm{G}_{(\%)}=68\left(1-\exp \left(-\left((\mathrm{x} / 21.77)^{\wedge 6.52}\right)\right)\right)$ & 0.99 \\
\hline 2 & $87.00 \pm 0.86$ & $19.54 \pm 0.03$ & $5.72 \pm 1.06$ & $\mathrm{G}_{(\%)}=87\left(1-\exp \left(-\left((\mathrm{x} / 19.54)^{\wedge 5.72}\right)\right)\right)$ & 0.99 \\
\hline 3 & $70.00 \pm 2.20$ & $21.77 \pm 0.45$ & $6.66 \pm 0.67$ & $\mathrm{G}_{(\%)}=70\left(1-\exp \left(-\left((\mathrm{x} / 21.77)^{\wedge 6.66}\right)\right)\right)$ & 0.99 \\
\hline 4 & $85.00 \pm 3.55$ & $21.98 \pm 0.52$ & $6.75 \pm 0.57$ & $\mathrm{G}_{(\%)}=85\left(1-\exp \left(-\left((\mathrm{x} / 21.98)^{\wedge 6.75}\right)\right)\right)$ & 0.99 \\
\hline 5 & $87.00 \pm 3.38$ & $22.26 \pm 0.44$ & $6.40 \pm 0.85$ & $\mathrm{G}_{(\%)}=87\left(1-\exp \left(-\left((\mathrm{x} / 22.26)^{\wedge 6.40}\right)\right)\right)$ & 0.99 \\
\hline $\begin{array}{c}\text { Temperature } \\
35^{\circ} \mathrm{C}\end{array}$ & \multicolumn{3}{|c|}{ Weibull regression parameters } & Weibull equation & $\mathrm{R}^{2}$ \\
\hline Lot $^{1}$ & $a$ & $b$ & $c$ & $G_{(\%)}=a\left(1-\exp \left(-\left((\mathrm{x} / b)^{\wedge c}\right)\right)\right)$ & - \\
\hline 1 & $35.00 \pm 6.93$ & $22.26 \pm 2.70$ & $3.62 \pm 1.43$ & $\mathrm{G}_{(\%)}=35\left(1-\exp \left(-\left((\mathrm{x} / 22.26)^{\wedge 3.62}\right)\right)\right)$ & 0.99 \\
\hline 2 & $36.00 \pm 1.02$ & $15.40 \pm 0.67$ & $5.10 \pm 1.34$ & $\mathrm{G}_{(\%)}=36\left(1-\exp \left(-\left((\mathrm{x} / 15.40)^{\wedge 5.10}\right)\right)\right)$ & 0.99 \\
\hline 3 & $40.00 \pm 2.24$ & $20.54 \pm 0.58$ & $4.86 \pm 0.93$ & $\mathrm{G}_{(\%)}=40\left(1-\exp \left(-\left((\mathrm{x} / 20.54)^{\wedge 4.86}\right)\right)\right)$ & 0.99 \\
\hline 4 & $62.00 \pm 16.41$ & $26.33 \pm 3.10$ & $4.59 \pm 1.23$ & $\mathrm{G}_{(\%)}=62\left(1-\exp \left(-\left((\mathrm{x} / 26.33)^{\wedge 4.59}\right)\right)\right)$ & 0.99 \\
\hline 5 & $68.00 \pm 13.69$ & $25.68 \pm 2.48$ & $4.14 \pm 0.62$ & $\mathrm{G}_{(\%)}=68\left(1-\exp \left(-\left((\mathrm{x} / 25.68)^{\wedge .14}\right)\right)\right)$ & 0.99 \\
\hline
\end{tabular}

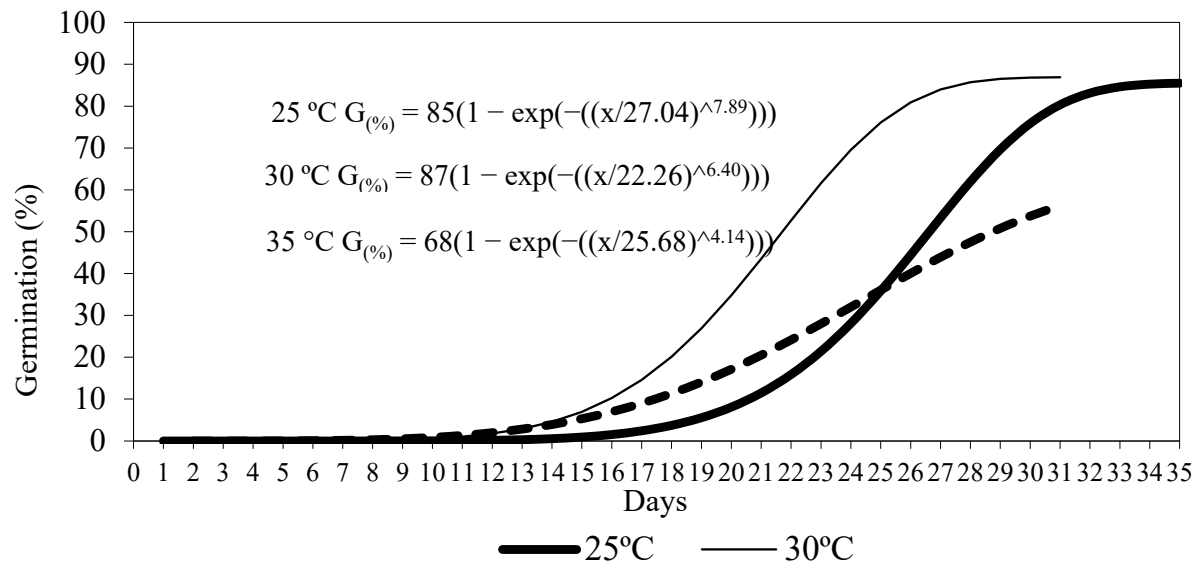

Figure 3. Regression curves by the three-parameter Weibull model of the accumulated germination (\%) as a function of time of Rangpur lime seeds of the lot 5 submitted to temperatures of 25,30 and $35^{\circ} \mathrm{C}$. 


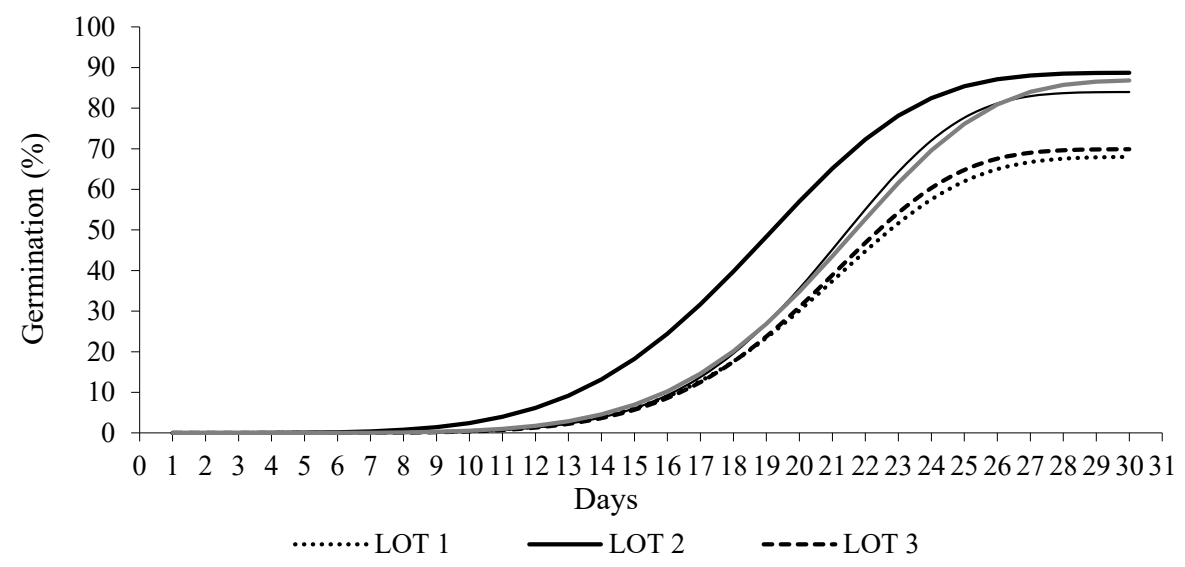

Figure 4. Regression curves by the three-parameter Weibull model of the accumulated germination (\%) of five lots of Rangpur lime seeds as a function of time (days) submitted to a temperature of $30^{\circ} \mathrm{C}$.

Because the germination test of Rangpur lime is not standardized in the Rules for Seed Testing (Brasil, 2009), the variable estimated time was used to obtain $63.21 \%$ of the maximum germination estimated by the regression to perform of the first germination test count $(b)$. This parameter indicates that the first count should be performed at 21 days, and germination can be finished at 30 days at a temperature of $30^{\circ} \mathrm{C}$.

The first germination count of Rangpur lime seeds is essential to verify if a lot has already reached $50 \%$ of germination and thus release it for commercialization without the need for the test completion, as the minimum germination requirement is 50\%, according to Brasil (2013).

Moreover, because it is a species with a recalcitrant characteristic, i.e., with a fast loss of seed viability during storage (Martins and Silva, 2006; Salisbury and Ross, 2012), it is essential the speed in obtaining reliable results safely to enable the lot to be marketed.

\section{Conclusions}

The germination test of Rangpur lime seeds presents better performance when conducted at $30^{\circ} \mathrm{C}$, with the first and last counts at 21 and 30 days after test installation, respectively.

The temperature of $25{ }^{\circ} \mathrm{C}$ favors the germination of Rangpur lime seeds, but it takes 35 days to complete the test.

The temperature of $35{ }^{\circ} \mathrm{C}$ impairs the germination performance of Rangpur lime seeds and is not recommended for conducting the germination test.

The germination performance of Rangpur lime seeds as a function of germination temperature can be described by a three-parameter Weibull distribution function model.

\section{References}

ARAÚJO-NETO, J.C.; AGUIAR, I.B.; FERREIRA, V.M.; RODRIGUES, T.J.D. Temperaturas cardeais e efeito da luz na germinação de sementes de mutamba. Revista Brasileira de Engenharia Agrícola e Ambiental, v.6, n.3, p.460-465, 2002. http:// agris.fao.org/agrissearch-/search.do?recordID $=$ XS2002250313

BRASIL. Ministério da Agricultura, Pecuária e Abastecimento. Regras para análise de sementes. Ministério da Agricultura, Pecuária e Abastecimento. Secretaria Nacional de Defesa Agropecuária. Brasília: MAPA/ACS, 2009. 395p. http://www.agricultura. gov.br/assuntos/insumos-agropecuarios/arquivos-publicacoesinsumos/2946_regras_analise_sementes.pdf

BRASIL. Ministério da Agricultura, Pecuária e Abastecimento. Normas para produção, comercialização e utilização de sementes. Padrões para produção e comercialização de sementes de Citrus. Instrução Normativa n.48, Anexo XV, de 24 de dezembro de 2013. Diário Oficial da União, Brasil, 25 de setembro de 2013. Seção 1. p.38. http://www.agricultura.gov.br/assuntos/insumosagropecuarios/insumos-agricolas/sementes-e-mudas/publicacoessementes-e-mudas/INN48de24desetembrode2013.pdf

CARNEIRO, J.W.P. Determinação do número de sementes para avaliar o desempenho germinativo de sementes de Stevia rebaudiana Bertoni. Revista Brasileira de Sementes, v.18, n.1, p.1-5, 1996. https://www.researchgate.net/profile/Jose_Pedroza_Carneiro/ publication/287933801_-Determinacao_do_numero_de_sementes para_avaliar_o_desempenho_germinativo_de_Stevia_Stevia_ rebaudiana_Bert_Bertoni/links/56838e6d08ae-1975839365d1/ Determinacao-do-numero-de-sementes-para-avaliar-o-desempenhogerminativo-de-Stevia-Stevia-rebaudiana-Bert-Bertoni.pdf

CARNEIRO, J.W.P.; GUEDES, T.A. Influência da temperatura no desempenho germinativo de sementes de cenoura (Daucus carota L.), avaliada pela função de distribuição de Weibull. Revista Brasileira de Sementes, v.14, n.2, p.207213, 1992. https://scielo.conicyt.cl/scielo.-php?script $=$ sci nlinks\&ref=3194660\&pid=S07183429201100030000600004\&lng 
CARNEIRO, J.W.P.; GUEDES, T.A. Avaliação do desempenho germinativo. Informativo ABRATES, v.2, n.4, p.28-30, 1993.

CARVALHO, J.A.; VON PINHO, E.V.R.; OLIVEIRA, J.A.; GUIMARÃES,R.M.;BONOME,L.T.Qualidadedesementesdelimãocravo (Citrus limonia Osbeck) durante o armazenamento. Revista Brasileira de Sementes, v.24, n.1, p.286-298, 2002. http://www. scielo.br/scielo.php?pid=S01011222002000100040\&script $=$ sci arttext\&tlng=es

DANTAS, I.B.; GUIMARÃES, R.M.; VON PINHO, E.V.R.; CARVALHO, M.L.M. Osmotic priming methodologies in relation to the physiological performance of rangpur lime seeds (Citrus limonia Osbeck). Revista Brasileira de Sementes, v.32, n.3, p.141-151, 2010. http://www.scielo.br/pdf/rbs/v32n3/v32n3a16.pdf

GASPAR-OLIVEIRA, C.M.; MARTINS, C.C.; NAKAGAWA, J.; CAVARIANI, C. Duração do teste de germinação de Brachiaria brizantha cv. Marandu (Hochst. ex A. Rich.) Stapf. Revista Brasileira de Sementes, v.30, n.3, p.30-38, 2008. http://www.scielo.br/pdf/rbs/ v30n3/05.pdf

GUEDES, T.A.; ROSSI, R.M.; MARTINS, A.B.T.; JANEIRO, V.; CARNEIRO, J.W.P. Nonlinear models applied to seed germination of Rhipsalis cereuscula Haw (cactaceae). Acta Scientiarum, v.36, n.4, p.651-656, 2014. http://www.redalyc.org/articulo. oa? $\mathrm{id}=303231830010$

JANDEL SCIENTIFIC. Table Curve $2 D$ Windows. v. 2.0. User's Manual. San Rafael: AISN Software Inc., 1994.

LOPES, R.R.; FRANKE, L.B. Aspectos térmico-biológicos da germinação de sementes de cornichão anual sob diferentes temperaturas. Revista Brasileira de Zootecnia, v.40, n.10, p.20912096, 2011. http://www.scielo.br/pdf/rbz/v40n10/v40n10a04.pdf

MARCOS-FILHO, J. Fisiologia de sementes de plantas cultivadas. Associação Brasileira de Tecnologia de Sementes, ABRATES: Londrina, $2^{\mathrm{a}}$ ed., 2015. 659p.

MARTINS, L.; SILVA, W.R. Comportamento fisiológico de sementes de tangerina (Citrus reticulata Blanco) submetidas à desidratação. Revista Brasileira de Fruticultura, v.28, n.1, p.8-10,2006. http://www. scielo.br/scielo.php?pid=S01009452006000100005\&script $=$ sci abstract-\&tlng=pt

McNAIR, J.N.; SUNKARA, A.; FROBISH, D. How to analyse seed germination data using statistical time-to-event analysis: nonparametric and semi-parametric methods. Seed Science Research, v.22, n.2, p.77-95, 2012. https://scholarworks.gvsu.edu/cgi/ viewcontent.cgi?-article $=1003 \&$ context $=$ peerscipub

MOBAYEN, R.G. Germination and emergence of citrus and tomato seeds in relation to temperature. Journal of Horticultural Science, v.55, n.3, p.291-297, 1980. https://doi.org/10.1080/00221589.1980.11514937

MONSELISE, S.P.; HALEVY, A.M. Effects of gibberellin and AMO1618 on growth, dry-matter accumulation, chlorophyll content and peroxidase activity of citrus seedlings. American Journal of Botany, v.49, n.4, p.405-412, 1962. DOI: $10.2307 / 2439082$
PINHEIRO, G.S.; ANGELOTTI, F.; SANTANA, C.V.S.; DANTAS, B.F.; COSTA, N.D. Efeito da temperatura sobre a germinação de sementes de cebola. Scientia Plena, v.10, n.11, p.1-6, 2014. https://ainfo. cnptia.embrapa.br/digital/bitstream/item/111228/1/Fran-2014.pdf

RAMÍREZ-TOBÍAS, H.M.; PEÑA-VALDIVIA, C.B.; AGUIRRE R., J.R.; REYES-AGÜERO, J.A.; SÁNCHEZ-URDANETA, A.B.; VALLE G., S. Seed germination temperatures of eight Mexican Agave species with economic importance. Plant Species Biology, v.27, n.2, p.124-137, 2012. https://onlinelibrary.wiley.com/doi/ full/10.1111/j.1442-1984.2011.00341.x

RITZ, C.; PIPPER, C.B.; STREIBIG, J.C. Analysis of germination data from agricultural experiments. European Journal of Agronomy, v.45, p.1-6, 2013. https://www.sciencedirect.com/science/article/pii/ S1161030112001360

RODRIGUES, F.A.; FREITAS, G.D.F.; MOREIRA, R.A.; PASQUAL, M. Caracterização dos frutos e germinação de sementes dos porta-enxertos trifoliata Flying Dragon e citrumelo Swingle. Revista Brasileira de Fruticultura, v.32, n.4, p.1180-1188, 2010. http://www.scielo.br/pdf/rbf/2010nahead/AOP12610.pdf

ROYO-ESNAL, A.; TORRA, J.; CONESA, J.A.; FORCELLA, F.; RECASENS, J. Modeling the emergence of three arable bedstraw (Galium) species. Weed Science, v.58, n.1, p.10-15, 2010. https:// www.jstor.org/stable/pdf/40586891.pdf

SALISBURY, F.B.; ROSS, C.W. Fisiologia das plantas. Cengage Learning. Wadsworth, Belmont, 2012. 774p.

SUÑÉ, A.D.; FRANKE, L.B. Superação de dormência e metodologias para testes de germinação em sementes de Trifolium riograndense Burkart e Desmanthus depressus Humb. Revista Brasileira de Sementes, v.28, n.3, p.29-36, 2006. http://www.scielo. br/pdf/rbs/v28n3/05.pdf

TAKAHASHI, L.; MELGES, E.; CARNEIRO, J.W.P. Desempenho germinativo de sementes de Stevia rebaudiana (Bert.) Bertoni sob diferentes temperaturas. Revista Brasileira de Sementes, v.18, n.1, p.6-9, 1996. https://www.researchgate.net/profile/ Jose_Pedroza_Carneiro/-publication/266319456_Germination_ performance_of_Stevia_seeds_under_different_temperatures/ links/542cf $25 \bar{b} 0$ cf $277 \mathrm{~d} 5 \overline{8} \mathrm{e} 8 \mathrm{c} 8 \mathrm{a} 32 /$ Germination-performance-ofStevia-seeds-under-different-temperatures.pdf

USBERTI, R.; FELIPPE, G.M. Alguns aspectos da germinação de sementes de limão-'Cravo' (Citrus limonia, Osb.): efeito deletério da reidratação lenta. Ciência e Cultura, v.32, n.8, p.1094-1098, 1980.

WAHID, A.; GELANI, S.; ASHRAF, M.; FOOLAD, M.R. Heat tolerance in plants: an overview. Environmental and Experimental Botany, v.61, n.3, p.199-223, 2007. https://www-sciencedirect.ez22. periodicos.capes.gov.br/science/article/pii/S0098847207000871/ pdfft?md5=e25edac20f5bfb6108b91162b970453b\&pid=1-s2.0S0098847207000871-main.pdf

WEIBULL, W. A statistical distribution function of wide applicability. Journal of Applied Mecanics, n.51, p.293-297, 1951. http://web. cecs.pdx.edu/ cgshirl/Documents/Weibull-ASME-Paper-1951.pdf 